\title{
Ammonia Synthesis via Non-Equilibrium Reaction of Lithium Nitride in Hydrogen Flow Condition*1
}

\author{
Kiyotaka Goshome ${ }^{1, * 2}$, Hiroki Miyaoka ${ }^{2}$, Hikaru Yamamoto ${ }^{1, * 3}$, Tomoyuki Ichikawa ${ }^{3}$, \\ Takayuki Ichikawa ${ }^{1,4, * 4}$ and Yoshitsugu Kojima ${ }^{1,4}$ \\ ${ }^{1}$ Graduate School of Advanced Sciences of Matter, Hiroshima University, Higashi-Hiroshima 739-8530, Japan \\ ${ }^{2}$ Institute for Sustainable Sciences and Development, Hiroshima University, Higashi-Hiroshima 739-8530, Japan \\ ${ }^{3}$ Hydrolabo Inc., Higashi-Hiroshima 739-8530, Japan \\ ${ }^{4}$ Institute for Advanced Materials Research, Hiroshima University, Higashi-Hiroshima 739-8530, Japan
}

Lithium nitride $\mathrm{Li}_{3} \mathrm{~N}$ is hydrogenated below $300^{\circ} \mathrm{C}$ under $0.5 \mathrm{MPa}$ of $\mathrm{H}_{2}$, and then $\mathrm{LiNH}_{2}$ and $\mathrm{LiH}$ are formed as products. Furthermore, the reaction between $\mathrm{LiNH}_{2}$ and $\mathrm{H}_{2}$ proceeds below $250^{\circ} \mathrm{C}$ under $0.5 \mathrm{MPa}$ of $\mathrm{H}_{2}$ flow condition, which forms $\mathrm{NH}_{3}$ and $\mathrm{LiH}$. In this study, we proposed and investigated another synthesis method of ammonia by combining these two reactions, which proceed in laboratory-scale under more moderate conditions than those of Haber-Bosch process. As a result, it was experimentally clarified that the ammonia synthesis were able to be operated below $300^{\circ} \mathrm{C}$ with realistic reactions rate by non-equilibrium reaction field under $0.5 \mathrm{MPa} \mathrm{H}_{2}$ flow condition, where a gas circuit system and a larger scale $\mathrm{NH}_{3}$ synthesis system were designed and assembled for the experiments. [doi:10.2320/matertrans.M2014382]

(Received October 29, 2014; Accepted December 17, 2014; Published February 6, 2015)

Keywords: ammonia synthesis, lithium nitride, non-equilibrium reaction

\section{Introduction}

Ammonia $\left(\mathrm{NH}_{3}\right)$ has been produced on massive scale in the world and used as various feedstock of nitrogenous chemical products. Recently, $\mathrm{NH}_{3}$ is regarded as hydrogen carrier for sustainable society, which potentially leads to strong demands for large-scale synthesis of $\mathrm{NH}_{3}$ with high efficiency and moreover laboratory-scale synthesis of high purity $\mathrm{NH}_{3}$ or deuterated ammonia $\left(\mathrm{ND}_{3}\right)$ for fundamental researches on $\mathrm{NH}_{3}$ utilization as energy carrier. ${ }^{1)}$ HaberBosch process is a well-known ammonia synthesis technique for industrialized mass production. The annual production of $\mathrm{NH}_{3}$ in the world by this Haber-Bosch process reached as much as 1.3 hundred million tons in 2010.2) Although this process is recognized as the most efficient method for large scale $\mathrm{NH}_{3}$ production, it needs high temperature of 400 $600^{\circ} \mathrm{C}$ and high pressure of $20-40 \mathrm{MPa}$ even in the presence of iron oxide catalyst. ${ }^{3,4)}$ Therefore, it should be difficult to adopt the process for the synthesis of high purity $\mathrm{NH}_{3}$ or $\mathrm{ND}_{3}$ in laboratory-scale.

The reason that the production of $\mathrm{NH}_{3}$ from $\mathrm{H}_{2}$ and $\mathrm{N}_{2}$ needs such high temperature and pressure even though the reaction is exothermic $\left(\Delta H=46 \mathrm{~kJ} / \mathrm{mol} \mathrm{NH}_{3}\right)$, is due to the strong triple bond between $\mathrm{N}$ atoms in $\mathrm{N}_{2}$ molecule. ${ }^{5)}$

\footnotetext{
${ }^{* 1}$ This Paper was Originally Published in Japanese in J. Japan Inst. Met. Mater. 77 (2013) 580-584. In order to more precisely explain the background, the experimental procedures, and the results, some parts of the contents were revised as follows. $\mathrm{X}$ ray diffraction profile of lithium nitride power and the corresponding patterns in database $\left(\alpha-\mathrm{Li}_{3} \mathrm{~N}\right.$; PDF\#75-8952 and $\beta-\mathrm{Li}_{3} \mathrm{~N}$; PDF\#76-0821) were added in Fig. 4 . The sentence of the abstract was slightly modified. References of 2-7), 15$19)$, and 20) were added and the reference of the Japanese website was removed from this paper.

${ }^{* 2}$ Graduate Student, Hiroshima University

${ }^{* 3}$ Hikaru Yamamoto who contributed to the development for the gas circuit apparatus is added as a coauthor in this paper on reconsidering the matter

${ }^{* 4}$ Corresponding author, E-mail: tichi@hiroshima-u.ac.jp
}

Therefore, it is an important issue how to dissociate $\mathrm{N}_{2}$ efficiently for $\mathrm{NH}_{3}$ synthesis under mild condition. In this view, the reaction of lithium (Li) with $\mathrm{N}_{2}$ attracts attention, described by the following reaction (1),

$$
6 \mathrm{Li}+\mathrm{N}_{2} \rightarrow 2 \mathrm{Li}_{3} \mathrm{~N} \text {. }
$$

Only $\mathrm{Li}$ is potential material to react with $\mathrm{N}_{2}$ below $100^{\circ} \mathrm{C}$, forming lithium nitride $\left(\mathrm{Li}_{3} \mathrm{~N}\right){ }^{6}{ }^{6}$ In other words, it is one of the simplest way to dissociate the nitrogen triple bond $(\mathrm{N} \equiv \mathrm{N})$, which possibly realizes the $\mathrm{NH}_{3}$ synthesis under milder condition by reaction between $\mathrm{Li}_{3} \mathrm{~N}$ and $\mathrm{H}_{2}$.

Therefore, we proposed $\mathrm{NH}_{3}$ synthesis process applying reactions of the amide-imide hydrogen storage system ${ }^{7-11)}$ and metal hydride-ammonia system, ${ }^{12-15)}$ respectively described by the following reactions,

$$
\begin{aligned}
& \mathrm{Li}_{3} \mathrm{~N}+2 \mathrm{H}_{2} \rightarrow 2 \mathrm{LiH}+\mathrm{LiNH}_{2}, \\
& \mathrm{LiNH}_{2}+\mathrm{H}_{2} \rightarrow \mathrm{NH}_{3}+\mathrm{LiH} .
\end{aligned}
$$

Since each reaction proceeds below $300^{\circ} \mathrm{C}$ and $0.5 \mathrm{MPa}$, it is expected that the $\mathrm{NH}_{3}$ synthesis process under moderate condition becomes possible by optimizing the reaction condition. Regarding the cycle of materials, Li should be regenerated from $\mathrm{LiH}$ as the final product in reaction (3). However, the thermal decomposition of $\mathrm{LiH}$ requires more than $500^{\circ} \mathrm{C}$. The effective regeneration process of Li metal below $300^{\circ} \mathrm{C}$ differently from simple decomposition is necessary, e.g. the metallic $\mathrm{Li}$ can be obtained below $500^{\circ} \mathrm{C}$ by using a reaction between crystalline graphite and LiH. ${ }^{16)}$

In this study, the reaction conditions of the proposed $\mathrm{NH}_{3}$ synthesis process from $\mathrm{Li}_{3} \mathrm{~N}$ were investigated by preparing various types of reaction systems, which were open system, closed gas circuit system, and closed system with gas exchange using hydrogen storage alloys, and the feasibility of the proposed process was discussed from the experimental results. 


\section{Experimental Procedure}

\subsection{Investigation of $\mathrm{NH}_{3}$ production from $\mathrm{Li}_{3} \mathrm{~N}$ by $\mathrm{DSC}$ and MS}

Commercial lithium nitride $\left(\mathrm{Li}_{3} \mathrm{~N}\right)(99.5 \%$, Aldrich) was used for the experiments in this work. The reaction of $\mathrm{Li}_{3} \mathrm{~N}$ with $\mathrm{H}_{2}$ for $\mathrm{NH}_{3}$ production was investigated by using differential scanning calorimetry (DSC) (TA Instruments, Q10 PDSC), which is installed into a glove box (Miwa MFG, MP-P60 W) filled with purified Ar (>99.9999\%). The generated gases during the DSC measurements is in-situ monitored by using mass spectrometry (MS) (Canon Anelva Corporation, M-100QA), which is connected to the reactor of DSC apparatus. The reaction condition using $\mathrm{H}_{2}$ flow is regarded as thermodynamic non-equilibrium state because the gaseous product, $\mathrm{NH}_{3}$, is immediately removed from the reaction field. The solid samples before and after the reaction were identified by X-ray diffraction (XRD) measurement (Rigaku, RINT-2100, CuKa radiation), where the samples were covered by a polyimide sheet (Du Pont-Toray Co., LTD., Kapton ${ }^{\circledR}$ ) to protect the samples from oxidation during XRD measurements.

\subsection{Investigation of $\mathrm{NH}_{3}$ production from $\mathrm{LiNH}_{2}$ in gas circuit system}

In order to realize the reaction (3) in closed system, a gas circuit system was designed. Figure 1 shows the schematic image of the gas circulating system designed for this experiment. This apparatus includes a gas densimeter (Yokogawa Electric Corporation, GD400), circulation pump (Nittou kouatsu), gas flow meter (ACE Inc., AFM-150), pressure gauge, and $\mathrm{NH}_{3}$ trap chamber. A reaction cell loading a weighed amount $(42 \mathrm{mg})$ of commercial $\mathrm{LiNH}_{2}$ $\left(\mathrm{LiNH}_{2}\right)(95 \%$, Aldrich) was connected to the gas circuit system and $0.5 \mathrm{MPa} \mathrm{H}_{2}$ with a molar ratio of $\mathrm{H}_{2} / \mathrm{LiNH}_{2}=$ 100 was introduced. After that, the experiments were carried out under gas circulated condition with 16 and $88 \mathrm{sccm}$ $\left(=\mathrm{cc} \mathrm{min}{ }^{-1}\right.$ at $\left.0.1 \mathrm{MPa}, 0^{\circ} \mathrm{C}\right)$ of flow rates at $300^{\circ} \mathrm{C} . \mathrm{NH}_{3}$ trap using liquid $\mathrm{N}_{2}$ was used to reduce the partial pressure of $\mathrm{NH}_{3}$ in the circuit system. In order to estimate the reaction yield, the amount of $\mathrm{NH}_{3}$ trapped during the reaction was measured by using a gas densimeter. The solid materials were identified by XRD before and after the reaction.

\subsection{Scale up test for $\mathrm{NH}_{3}$ and $\mathrm{ND}_{3}$ synthesis}

Mixture of $\mathrm{LiD}$ and $\mathrm{LiND}_{2}$ were synthesized as starting materials for this experiments by reaction between $\mathrm{Li}_{3} \mathrm{~N}$ (99.5\%, Aldrich) and high purity $\mathrm{D}_{2}$ gas $(>99.8 \%)$ instead of the reaction (2). In order to realize a certain amount of $\mathrm{D}_{2}$ flow condition for the reaction (3), gas collecting system by hydrogen storage alloys without waste of $\mathrm{D}_{2}$ was designed and assembled. Figure 2 shows the schematic image of the closed $\mathrm{H}_{2}$ flow system used for scale up test. This system is composed of reaction cell, hydrogen storage tanks, heaters, pressure gauge, flow meter, and $\mathrm{NH}_{3}$ trap. The couple of tanks loaded by the same hydrogen storage alloy were connected to both ends of reaction cell and thermally controlled. Then, a sufficient amount of mixture of LiD and $\mathrm{LiND}_{2}$ loaded in the reaction cell and heated under $\mathrm{D}_{2}$ flow condition $\left(1.0 \mathrm{MPa}, 1.0 \mathrm{~L} \mathrm{~min}^{-1}\right)$ at $300^{\circ} \mathrm{C}$ with $\mathrm{ND}_{3}$ trap.

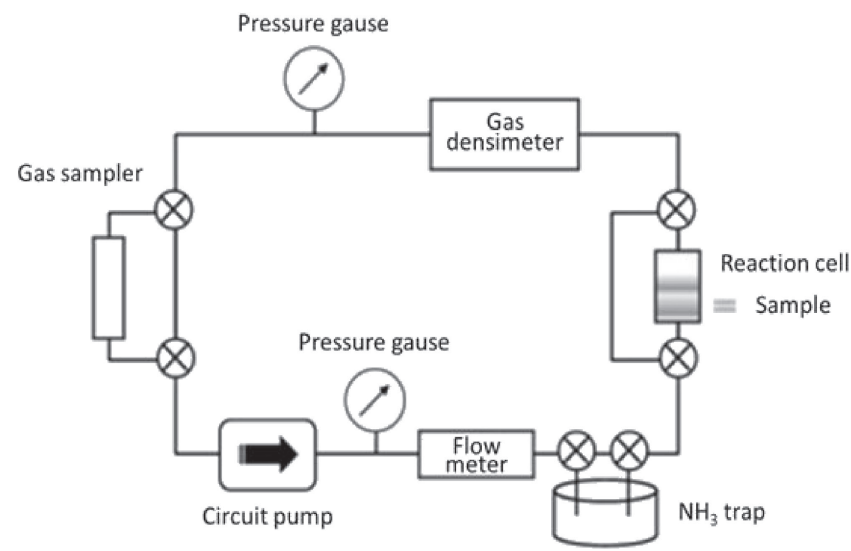

Fig. 1 Schematic view of gas circuit system.

After the reaction, the amount of generated $\mathrm{ND}_{3}$ in the trap was weighted.

\section{Result and Discussions}

\subsection{Investigation of $\mathrm{NH}_{3}$ production from $\mathrm{Li}_{3} \mathrm{~N}$ by $\mathrm{DSC}$ and MS}

Hydrogenation of $\mathrm{Li}_{3} \mathrm{~N}$ under $\mathrm{H}_{2}$ flow was investigated by DSC and MS. Since the $\mathrm{NH}_{3}$ production reaction of $\mathrm{LiH}-\mathrm{NH}_{3}$ system described by reaction (3) is endothermic reaction, the thermodynamics should be considered to control the reaction process at a moderate temperature. Gibbs free energy change $\Delta G$ on this reaction is expressed as follows,

$$
\Delta G=\Delta H-T\left(\Delta S^{0}+\mathrm{R} \ln \left(P_{\mathrm{H}_{2}} / P_{\mathrm{NH}_{3}}\right)\right)
$$

where $\Delta H, \Delta S^{0}, \mathrm{R}, P_{\mathrm{H}_{2}}$, and $P_{\mathrm{NH}_{3}}$ are, respectively, the enthalpy change, the standard entropy change, the gas constant, partial pressure of $\mathrm{H}_{2}$, and partial pressure of $\mathrm{NH}_{3}$. In order to manage the reaction progress at lower temperature, it is essential to decrease the value of the last entropy term in the equation (4). In the DSC-MS experiments, the reaction was investigated under the $\mathrm{H}_{2}$ flow condition in an open system, suggesting that the value of the entropy is increased by reducing $P_{\mathrm{NH}_{3}}$. Figure 3 shows the DSC-MS profile of $\mathrm{Li}_{3} \mathrm{~N}$ under $0.5 \mathrm{MPa}$ of the $\mathrm{H}_{2}$ flow condition. As shown in this DSC profile, exothermic peak was observed from $200^{\circ} \mathrm{C}$ during heating, which would be originated in the hydrogenation of $\mathrm{Li}_{3} \mathrm{~N}$ described by the reaction (2). The temperature for this reaction is consistent with the results reported before. ${ }^{8)}$ It is also possible that the reaction (3) proceeds $200^{\circ} \mathrm{C}$ in this condition. ${ }^{14)}$ However, it is difficult to distinguish the reaction temperature because the smaller endothermic peak due to the reaction (3) would be overlapped with the larger exothermic peak due to the reaction (2). In the mass spectra, generation of $\mathrm{NH}_{3}$ gas was clearly observed above $230^{\circ} \mathrm{C}$. It was expected that the $\mathrm{NH}_{3}$ generation originated in hydrogenation of $\mathrm{LiNH}_{2}$. The onset temperature for $\mathrm{NH}_{3}$ desorption was about $230^{\circ} \mathrm{C}$, which was closed to that reported before. ${ }^{14)}$ The $\mathrm{NH}_{3}$ desorption intensity was increased with during the heating, indicating that the reaction (3) gradually proceeds from $230^{\circ} \mathrm{C}$ after the $\mathrm{LiNH}_{2}$ formation by the reaction (2) around $200^{\circ} \mathrm{C}$. Here, the MS detection of our experimental system is slightly delayed 


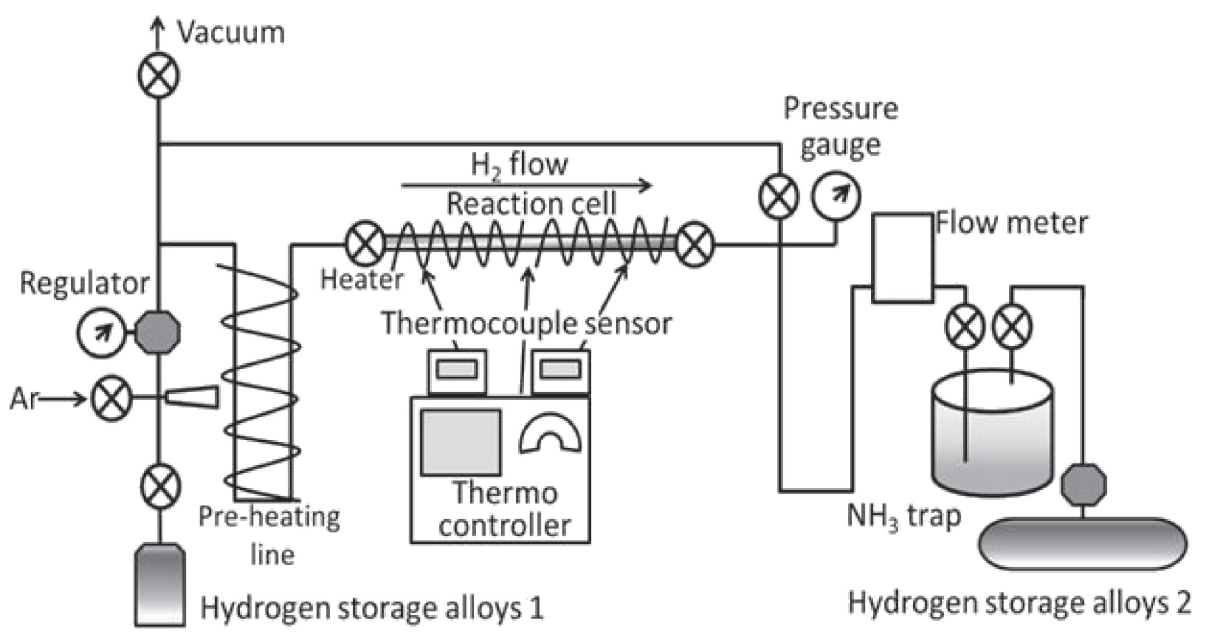

Fig. 2 Schematic view of $\mathrm{D}_{2}$ flow system for $\mathrm{ND}_{3}$ synthesis.

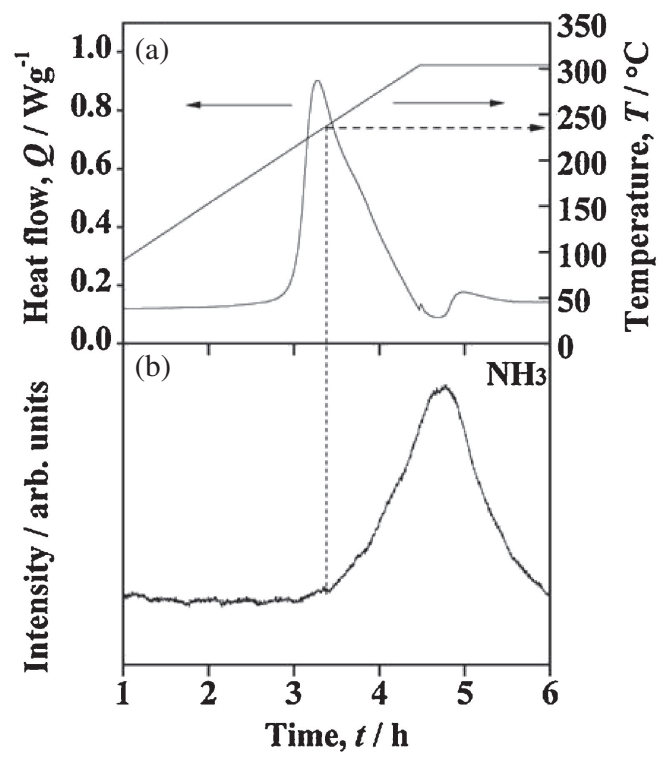

Fig. 3 DSC (a)-MS (b) profiles of $\mathrm{Li}_{3} \mathrm{~N}$ under $0.5 \mathrm{MPa}$ of $\mathrm{H}_{2}$ flow condition at $1.0^{\circ} \mathrm{Cmin}^{-1}$ heating rate. $\mathrm{NH}_{3}$ generation temperature is indicated with the auxiliary line (---).

from the DSC signal with fast response, and the reaction kinetics of the light elements based materials are generally slow. From the above facts, it is suggested that the accurate reaction temperature of (3) is difficult to be distinguished. Figure 4 shows XRD pattern of the product after the DSCMS measurement. The X-ray diffraction peaks of $\mathrm{LiH}$ was observed as the reaction product without any traces for the diffraction peaks of $\mathrm{Li}_{3} \mathrm{~N}$ and $\mathrm{LiNH}_{2}$. This indicates that the $\mathrm{LiNH}_{2}$ generated by the prior hydrogenation of $\mathrm{Li}_{3} \mathrm{~N}$ gradually reacted with $\mathrm{H}_{2}$ to form $\mathrm{NH}_{3}$ and $\mathrm{LiH}$. Here, $\mathrm{Li}_{2} \mathrm{O}$ phase observed in XRD profile would be derived from impurity in the reagent. Generally, X-ray diffraction intensity is strongly related to electron number of atoms in the material. If the amount of $\mathrm{Li}_{2} \mathrm{O}$ is considerable in the samples, the diffraction intensity has to be much stronger than that of $\mathrm{LiH}$. Thus, it is considered that the amount of the impurity was small by taking account of the intensity of $\mathrm{LiH}$ phase and $\mathrm{Li}_{2} \mathrm{O}$ phase, suggesting that any effects of the impurity into the essential reaction could be negligible. From

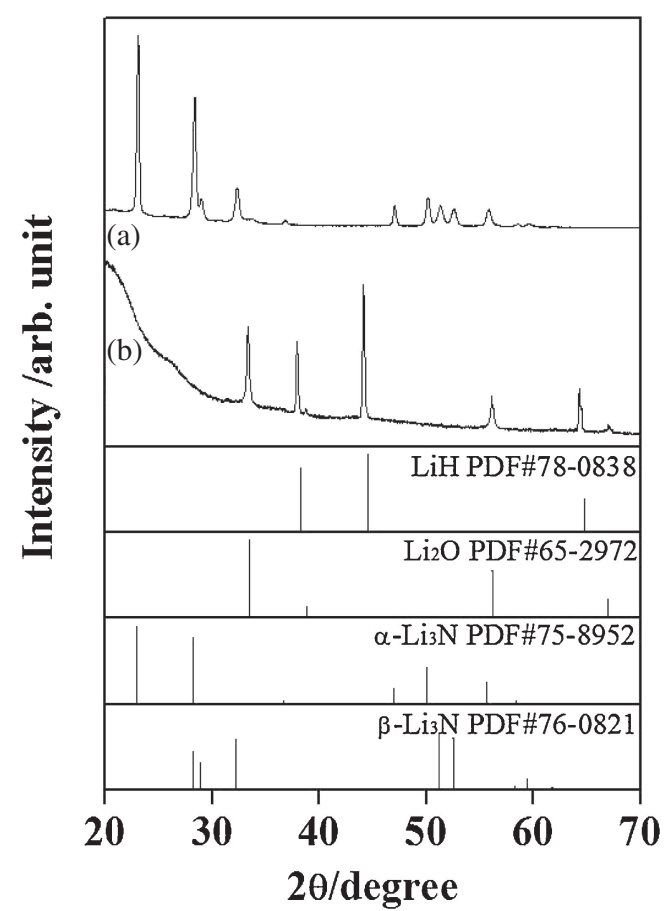

Fig. 4 XRD patterns of $\mathrm{Li}_{3} \mathrm{~N}$ before: (a) and after: (b) the treatment under $\mathrm{H}_{2}$ flow condition for $4 \mathrm{~h}$ at $300^{\circ} \mathrm{C}$. XRD pattern of $\mathrm{LiH}$ (PDF\#78-0838), $\mathrm{Li}_{2} \mathrm{O}$ (PDF\#65-2972), $\alpha-\mathrm{Li}_{3} \mathrm{~N}$ (PDF\#75-8952) $\beta$ - $\mathrm{Li}_{3} \mathrm{~N}$ (PDF\#76-0821) are referred from databases.

the above results, it was confirmed that the objective twostep process for $\mathrm{NH}_{3}$ production proceeded under relatively lower temperature and pressure in the $\mathrm{H}_{2}$ flow condition. In thermodynamic analyses based on the experimental results and equation (4), the partial pressure of $\mathrm{NH}_{3}$ is reduced to be $4 \sim 12 \mathrm{~Pa}$ as an overestimation under the experimental conditions, where the $\Delta H$ and $\Delta S^{0}$ were calculated by combining reported $\Delta^{\mathrm{f}} H^{\mathrm{o}}$ and $S^{0}$ values as shown in Table 1 , $-90.5 \mathrm{~kJ} \mathrm{~mol}^{-1}$ and $20.0 \mathrm{~J} \mathrm{~mol}^{-1} \mathrm{~K}^{-1}$ for $\mathrm{LiH}, \quad-45.9$ $\mathrm{kJ} \mathrm{mol}^{-1}$ and $192.8 \mathrm{~J} \mathrm{~mol}^{-1} \mathrm{~K}^{-1}$ for $\mathrm{NH}_{3}, 130.7 \mathrm{~J} \mathrm{~mol}^{-1} \mathrm{~K}^{-1}$ for $\mathrm{H}_{2},-179.5 \mathrm{~kJ} \mathrm{~mol}^{-1}$ for $\mathrm{LiNH}_{2},{ }^{17-19)}$ and approximate $S^{0}$ values of $\mathrm{LiNH}_{2}, 80-90 \mathrm{~J} \mathrm{~mol}^{-1} \mathrm{~K}^{-1}$ which is similar to the $S^{0}$ value of complex hydrides such as $\mathrm{LiBH}_{4}$ and $\mathrm{LiAlH}_{4}{ }^{20)}$ 
Table 1 Standard enthalpy of formation and standard entropy for $\mathrm{H}_{2}, \mathrm{NH}_{3}$, $\mathrm{LiH}$, and $\mathrm{LiNH}_{2}$.

\begin{tabular}{ccc}
\hline Compounds & $\begin{array}{c}\text { Enthalpy of formation } \Delta_{\mathrm{f}} H^{\mathrm{o}} \\
\left(\mathrm{kJ} \cdot \mathrm{mol}^{-1}\right)\end{array}$ & Entropy $S^{\mathrm{o}}\left(\mathrm{J} \cdot \mathrm{K}^{-1} \cdot \mathrm{mol}^{-1}\right)$ \\
\hline $\mathrm{LiH}(\mathrm{s})$ & -90.5 & 20 \\
$\mathrm{LiNH}_{2}(\mathrm{~s})$ & -179.5 & $80-90^{*}$ \\
$\mathrm{H}_{2}(\mathrm{~g})$ & 0 & 130.7 \\
$\mathrm{NH}_{3}(\mathrm{~g})$ & -45.9 & 192.8 \\
\hline
\end{tabular}

*Assumed $S^{0}$ value for $\mathrm{LiNH}_{2}$.

\subsection{Investigation of $\mathrm{NH}_{3}$ production from $\mathrm{LiNH}_{2}$ in gas circuit system}

From the above DSC experiments, the feasibility of $\mathrm{NH}_{3}$ generation from $\mathrm{Li}_{3} \mathrm{~N}$ under $\mathrm{H}_{2}$ flow was demonstrated. In the process, the reaction (2) is not difficult to be operated because this exothermic reaction proceeds even at closed system. In order to control the proposed $\mathrm{NH}_{3}$ production process, the most important issue is how to control the reaction (3). Thus, the hydrogenation property of $\mathrm{LiNH}_{2}$ was further investigated in closed-circuit system. For the experiment, the gas circuit apparatus was used as mentioned in the experimental part. By using the gas circuit system, it becomes possible to in-situ measure the concentration of $\mathrm{H}_{2}$ for $\mathrm{NH}_{3}$ under a certain pressure and gas flow rate in the circulating system. Additionally, $\mathrm{NH}_{3}$ trap by using liquid $\mathrm{N}_{2}$ is equipped into the circulating line, thus the generated $\mathrm{NH}_{3}$ can be removed from the circulated gases. It is expected that the partial pressure of $\mathrm{NH}_{3}$ is reduced to a sufficient level to realize the progress of reaction (3) because the temperature of liquid $\mathrm{N}_{2}$ is low enough compared with the freezing point of $\mathrm{NH}_{3}$. Here, the inner volume of the trap part is sufficiently-large. Thus, almost all the generated $\mathrm{NH}_{3}$ can be trapped even if the experiments are performed by a maximum circuit rate, in other words, the generated $\mathrm{NH}_{3}$ is not reached to sample part again during the circulation. As described above, it is essential to control the entropy change by reducing $\mathrm{NH}_{3}$ partial pressure for the hydrogenation of $\mathrm{LiNH}_{2}$. Therefore, the investigation for hydrogenation reaction of $\mathrm{Li}_{3} \mathrm{~N}$ was performed under $\mathrm{H}_{2}$ flow condition in open system by DSC$\mathrm{MS}$ in section 3.1. However, such flow condition, which exhausts unreacted $\mathrm{H}_{2}$ and generated $\mathrm{NH}_{3}$ gases, is totally different from practical condition, because the hydrogen gas has to be consumed a lot in the open system. On the other hand, in the case of above gas circuit system, it is expected that the hydrogenation reaction proceeds even in closed system without the $\mathrm{H}_{2}$ loss, which would be more practical condition than that of DSC experiments. Figure 5 shows XRD pattern of the product after the $\mathrm{LiNH}_{2}$ hydrogenating treatment for $8 \mathrm{~h}$ at $300^{\circ} \mathrm{C}$, where the circulating rate was $16 \mathrm{sccm}$. Although diffraction peaks corresponding to $\mathrm{LiH}$ was observed, it was confirmed that a trace of $\mathrm{LiNH}_{2}$ remained in the product. In this case, the reaction yield was $35.6 \%$. These results indicated that the $P_{\mathrm{NH}_{3}}$ was reduced to less than $12 \mathrm{~Pa}$ and the reaction proceeded by using the circulating system because $\mathrm{LiH}$ was clearly generated. However, the $16 \mathrm{sccm}$ of circuit rate was not enough to reach the same level of $P_{\mathrm{NH}_{3}}$ as the DSC condition due to slow diffusion rate of $\mathrm{NH}_{3}$ gas in the solid sample part,

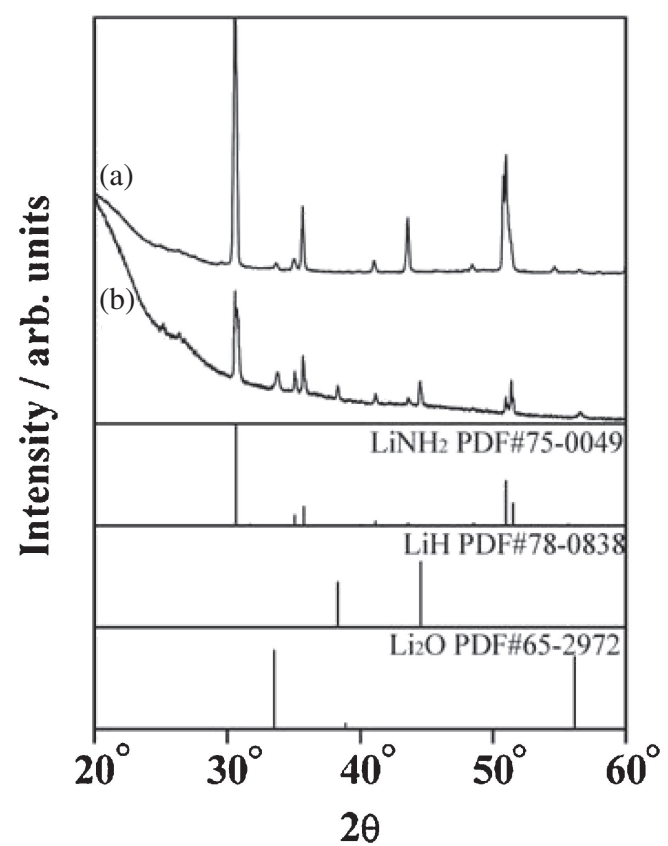

Fig. 5 XRD patterns of $\mathrm{LiNH}_{2}$ before: (a) and after: (b) the treatment under $16 \mathrm{sccm} \mathrm{H}_{2}$ flow condition for $8 \mathrm{~h}$ at $300^{\circ} \mathrm{C}$. XRD pattern of $\mathrm{LiNH}_{2}$ (PDF\#75-0049), $\mathrm{LiH}$ (PDF\#78-0838), and $\mathrm{Li}_{2} \mathrm{O}$ (PDF\#65-2972) are referred from databases.

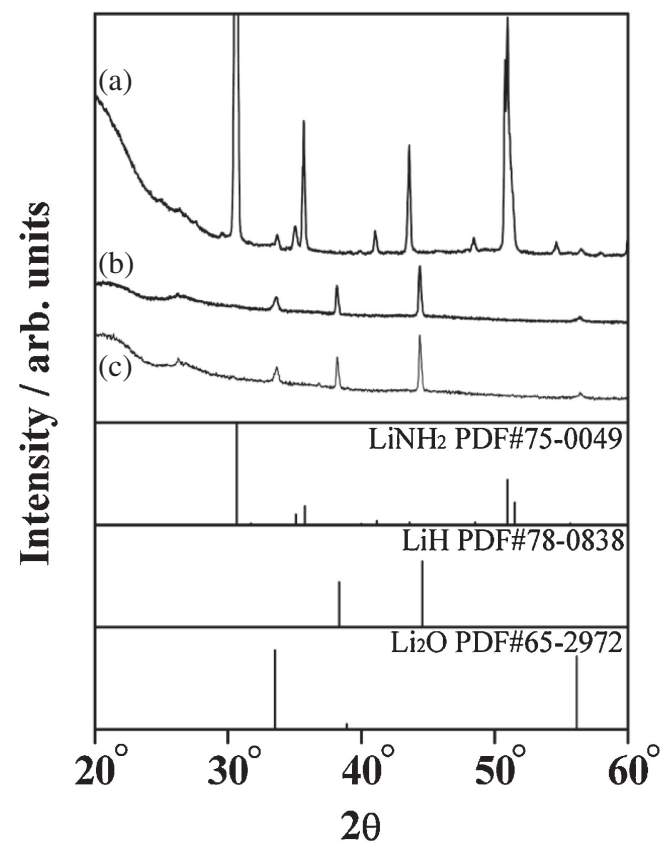

Fig. 6 XRD patterns of $\mathrm{LiNH}_{2}$ before: (a) and after the treatment under $88 \mathrm{sccm} \mathrm{H}_{2}$ flow condition for $4 \mathrm{~h}$ : (b) and $6 \mathrm{~h}$ : (c) at $300^{\circ} \mathrm{C}$. XRD pattern of $\mathrm{LiNH}_{2}$ (PDF\#75-0049), LiH (PDF\#78-0838), and $\mathrm{Li}_{2} \mathrm{O}$ (PDF\#652972) are referred from databases.

indicating that $\mathrm{NH}_{3}$ was not removed enough from reaction field. Therefore, the reaction condition was changed to higher circulating rate of $88 \mathrm{sccm}$. Figure 6 shows XRD pattern of the product in circulating system for $4 \mathrm{~h}$ and $6 \mathrm{~h}$ at $300^{\circ} \mathrm{C}$. The diffraction peaks corresponding to $\mathrm{LiNH}_{2}$ observed after the experiments with $16 \mathrm{sccm}$ totally disappeared. Here, in these experiments, although a small amount of $\mathrm{Li}_{2} \mathrm{O}$ derived from impurity in the reagent was observed by XRD, it would 
not influence the quantitative discussion because of the same reason as section 3.1. The reaction yields for 4 and $6 \mathrm{~h}$ were estimated from $\mathrm{NH}_{3}$ concentration by using the gas densimeter, and the values were respectively $75.3 \%$ and 91.6\%. As described above, it is important to decrease the partial pressure of $\mathrm{NH}_{3}$ by diffusing $\mathrm{NH}_{3}$ gas effectively from the reaction field for the reaction (3). In this experiment by using gas circulating system, the gas in the closed system was circulated and simultaneously $\mathrm{NH}_{3}$ was trapped. As the results, sufficiently low $P_{\mathrm{NH}_{3}}$ and highly efficient condition for $\mathrm{NH}_{3}$ production can be realized when the faster circulating rate.

\subsection{Scale up test for $\mathrm{ND}_{3}$ synthesis}

The scale up test of the reaction (3) for the $\mathrm{ND}_{3}$ synthesis was performed. As described above, a certain diffusion rate of generated $\mathrm{NH}_{3}$ from reaction field is important for efficient $\mathrm{NH}_{3}$ production from $\mathrm{LiNH}_{2}$. Therefore, it is necessary to make the higher $\mathrm{H}_{2}$ flow rate for larger scale $\mathrm{NH}_{3}$ production. Thus, the gas flow system with higher $\mathrm{H}_{2}$ flow rate by hydrogen storage alloys was designed and assembled. When the temperatures of the tanks were controlled in high and low temperatures, the pressure gradient was generated because of different $\mathrm{H}_{2}$ equilibrium pressure of the hydrogen storage alloy. By this pressure difference, it was expected that the sufficient $\mathrm{H}_{2}$ flow condition through reaction cell is realized. In this process, the unreacted $\mathrm{H}_{2}$ is collected into the alloys controlled at lower temperature, and $\mathrm{H}_{2}$ can be reused by exchanging the flow direction with temperature control of tanks. As a result, the $\mathrm{H}_{2}$ loss except the $\mathrm{NH}_{3}$ generation reaction is suppressed, where this would be advantage point as productive $\mathrm{NH}_{3}$ synthesis. In the actual experiment, we used $\mathrm{D}_{2}$ gas instead of $\mathrm{H}_{2}$ gas. Then the pressure and flow rate of inside gas were monitored, and the generated $\mathrm{ND}_{3}$ was collected in the trap. It was clarified that flow rate prepared by this reaction system was $1.0 \mathrm{~L} \mathrm{~min}^{-1}$, which is approximately ten times faster than that required in the above circulating system to complete the reaction. By using this reaction system, $1.0 \mathrm{~g} \mathrm{ND}_{3}$ was successfully produced by heating the mixture of $\mathrm{LiD}$ and $\mathrm{LiND}_{2}$ in $1.0 \mathrm{MPa}$ of $\mathrm{D}_{2}$ flow condition with $1.0 \mathrm{~L} \mathrm{~min}^{-1}$ of flow rate at $300^{\circ} \mathrm{C}$ for $4 \mathrm{~h}$, resulting in $0.25 \mathrm{~g} \mathrm{~h}^{-1}$ of production rate. Whereas HaberBosch process needs high temperature of $400-600^{\circ} \mathrm{C}$ and high pressure of $20-40 \mathrm{MPa}$, the result in this study indicates that the $\mathrm{NH}_{3}$ production by the reactions (1) and (2) can be operated under comparatively mild condition and is remarkably useful as efficient $\mathrm{ND}_{3}$ synthesis method in laboratoryscale.

\section{Conclusions}

In this work, $\mathrm{NH}_{3}$ production by the hydrogenation $\mathrm{Li}_{3} \mathrm{~N}$ and the reaction of $\mathrm{LiNH}_{2}$ and $\mathrm{H}_{2}$ were investigated to propose a novel $\mathrm{NH}_{3}$ synthesis method in laboratory-scale.
As a result, the $\mathrm{NH}_{3}$ generation from $\mathrm{Li}_{3} \mathrm{~N}$ in $0.5 \mathrm{MPa}$ of $\mathrm{H}_{2}$ flow condition below $300^{\circ} \mathrm{C}$ was confirmed by DSC-MS and XRD, indicating that the $\mathrm{NH}_{3}$ production from $\mathrm{Li}_{3} \mathrm{~N}$ can proceed in milder condition than conventional method by using the objective two step reactions. For the investigation of $\mathrm{NH}_{3}$ generation from $\mathrm{LiNH}_{2}$ in the closed system, a gas circuit system was designed and used for the experiment. The system can circulate mixture gas of $\mathrm{NH}_{3}$ and $\mathrm{H}_{2}$ with enough flow rate and reduce the partial pressure of $\mathrm{NH}_{3}$ by the trap using liquid $\mathrm{N}_{2}$. As a result, it was clarified that $\mathrm{NH}_{3}$ generation proceeded even in the closed system, which would be considered as more practical condition. Furthermore, $\mathrm{NH}_{3}$ synthesis test on a larger scale was conducted, where the higher $\mathrm{D}_{2}$ flow system by pressure gradient between couple of hydrogen storage alloy tanks was designed for the experiment. By using the system, a certain amount of $\mathrm{ND}_{3}$ production at realistic reaction rate $\left(0.25 \mathrm{gh}^{-1}\right)$ was demonstrated in $1.0 \mathrm{~L} \mathrm{~min}^{-1}$ of $\mathrm{D}_{2}$ flow condition below $300^{\circ} \mathrm{C}$ and $1.0 \mathrm{MPa}$.

\section{REFERENCES}

1) U.S. Department of Energy: Potential Roles of Ammonia in a Hydrogen Economy, http://www.hydrogen.energy.gov/pdfs/nh3_paper. pdf

2) R. Lan, J. T. S. Irvine and S. W. Tao: Int. J. Hydrogen Energy 37 (2012) 1482-1494.

3) A. Barański, A. Kotarba, J. M. Lagan, A. Pattekjanczyk, E. Pyrczak and A. Reizer: Appl. Catal. A-Gen. 112 (1994) 13-36.

4) T. Kandemir, M. E. Schuster, A. Senyshyn, M. Behrens and R. Schlogl: Angew. Chem. Int. Ed. 52 (2013) 12723-12726.

5) N. D. Spencer, R. C. Schoonmaker and G. A. Somorjai: J. Catal. 74 (1982) 129-135.

6) T. Arakawa and K. Takizawa: JP2002-3209A (2002).

7) P. Chen, Z. T. Xiong, J. Z. Luo, J. Y. Lin and K. L. Tan: J. Phys. Chem. B 107 (2003) 10967-10970.

8) P. Chen, Z. T. Xiong, J. Z. Luo, J. Y. Lin and K. L. Tan: Nature 420 (2002) 302-304.

9) T. Ichikawa, N. Hanada, S. Isobe, H. Y. Leng and H. Fujii: J. Phys. Chem. B 108 (2004) 7887-7892.

10) T. Ichikawa, S. Isobe, N. Hanada and H. Fujii: J. Alloy. Compd. 365 (2004) 271-276.

11) S. Isobe, T. Ichikawa, S. Hino and H. Fujii: J. Phys. Chem. B 109 (2005) 14855-14858.

12) H. Miyaoka, H. Fujii, H. Yamamoto, S. Hino, H. Nakanishi, T. Ichikawa and Y. Kojima: Int. J. Hydrogen Energy 37 (2012) 1602516030.

13) H. Miyaoka, T. Ichikawa, S. Hino and Y. Kojima: Int. J. Hydrogen Energy 36 (2011) 8217-8220.

14) H. Yamamoto, H. Miyaoka, S. Hino, H. Nakanishi, T. Ichikawa and Y. Kojima: Int. J. Hydrogen Energy 34 (2009) 9760-9764.

15) Y. H. Hu and E. Ruckenstein: J. Phys. Chem. A 107 (2003) 9737-9739.

16) H. Miyaoka, W. Ishida, T. Ichikawa and Y. Kojima: J. Alloy. Compd. 509 (2011) 719-723.

17) D. R. Lide: CRC Handbook of Chemistry and Physics, 89th ed., (CRC press, London, 2008).

18) M. W. Chase: J. Phys. Chem. Ref. Data Monogr. 9 (1998) 1224-1293.

19) S. Hino, N. Ogita, M. Udagawa, T. Ichikawa and Y. Kojima: J. Appl. Phys. 105 (2009) 023527.

20) NIST Web book, http://webbook.nist.gov/chemistry 